\title{
Diffuse large B-cell lymphoma with involvement of the kidney
}

\author{
Tomomi Takei, Michihiro Uchiyama \\ Department of Hematology, Suwa Red Cross Hospital, Suwa, Nagano, Japan \\ Correspondence to Dr Michihiro Uchiyama, mi.uchiyama@suwa.jrc.or.jp
}

\section{DESCRIPTION}

A 59-year-old woman visited our hospital with a 2-week history of numbness over the left buttock and lateral aspect of the left thigh in December 2011. Contrastenhanced CT showed a retroperitoneal mass anterior to the left wing of the ileum, infiltrating the left sacral foramen. Contrast-enhanced CT showed bilateral soft-tissue renal masses partially deforming the contours of the kidneys (figure 1). Increased uptake in these masses was evident on positron emission tomography (PET)-CT (figure 1). Diffuse large B-cell lymphoma (DLBCL) was diagnosed from CT-guided percutaneous needle biopsy of the retroperitoneal mass. The patient was staged as IVA, and treated with six cycles of rituximab-cyclophosphamidedoxorubicine-vincristine-prednisolone therapy. Complete remission was achieved after therapy.

Renal involvement appears uncommon in DLBCL, although some reports from autopsy series of lymphoma patients have suggested that renal involvement may actually be relatively common. ${ }^{1}$ This may be because renal lymphoma is clinically silent and radiological findings are missing. Recently, patients with DLBCL and kidney involvement at diagnosis have shown poor prognosis, due in part to the high incidence of central nervous system relapse. $^{2}$ Although fluorodeoxyglucose is excreted renally and increased uptake in the kidneys is usually related to this, PET-CT combined with CT could help determine DLBCL involvement.

\section{Learning points}

- Radiological findings of renal involvement of diffuse large B-cell lymphoma seem uncommon due to the asymptomatic nature of this pathology.

- Positron emission tomography-CT combined with CT is a powerful tool for staging and defining treatment strategies.

Competing interests None.

Patient consent Obtained.

\section{REFERENCES}

1. Richards MA, Mootoosamy I, Reznek RH, et al. Renal involvement in patients with non-Hodgkin's lymphoma: clinical and pathological features in 23 cases. Hematol Oncol 1990;8:105-10.

2. Villa D, Connors JM, Sehn LH, et al. Diffuse large B-cell lymphoma with involvement of the kidney: outcome and risk of central nervous system relapse. Haematologica 2011;96:1002-7.
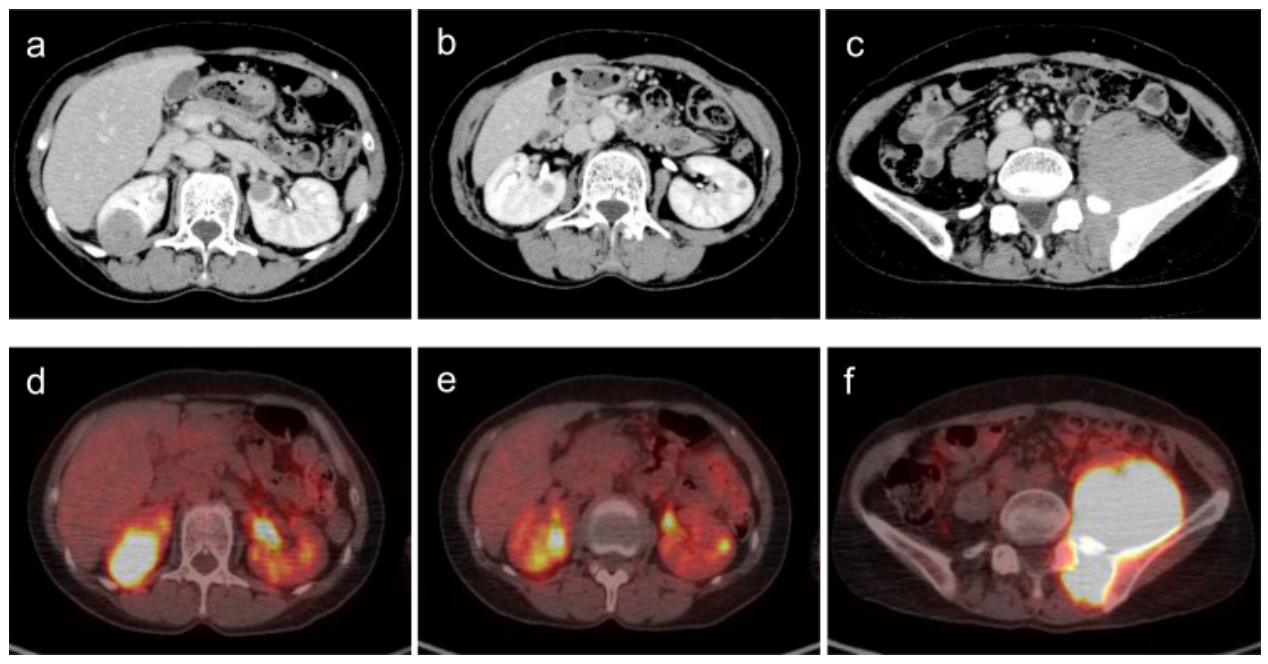

Figure 1 Contrast-enhanced CT showed a retroperitoneal mass anterior to the left wing of the ileum, infiltrating the left sacral foramen, and also showed bilateral soft-tissue renal masses partially deforming the contours of the kidneys. Increased uptake in these masses was evident on positron emission tomography-CT. 


\section{BMJ Case Reports}

This pdf has been created automatically from the final edited text and images.

Copyright 2012 BMJ Publishing Group. All rights reserved. For permission to reuse any of this content visit http://group.bmj.com/group/rights-licensing/permissions.

BMJ Case Report Fellows may re-use this article for personal use and teaching without any further permission.

Please cite this article as follows (you will need to access the article online to obtain the date of publication).

Takei T, Uchiyama M. Diffuse large B-cell lymphoma with involvement of the kidney. BMJ Case Reports 2012;10.1136/bcr-2012-006281, Published XXX

Become a Fellow of BMJ Case Reports today and you can:

- Submit as many cases as you like

- Enjoy fast sympathetic peer review and rapid publication of accepted articles

- Access all the published articles

- Re-use any of the published material for personal use and teaching without further permission

For information on Institutional Fellowships contact consortiasales@bmjgroup.com

Visit casereports.bmj.com for more articles like this and to become a Fellow 